\title{
DNA2 wt Allele
}

National Cancer Institute

\section{Source}

National Cancer Institute. DNA2 wt Allele. NCI Thesaurus. Code C117092.

Human DNA2 wild-type allele is located within 10q21.3-q22.1 and is approximately $58 \mathrm{~kb}$ in length. This allele, which encodes DNA replication ATP-dependent helicase/nuclease DNA2 protein, plays a role in DNA replication and repair. Mutation of the gene is associated with autosomal dominant progressive external ophthalmoplegia with mitochondrial DNA deletions type 6 and may be associated with Seckel Syndrome 8. 